\title{
Pelatihan Analisis Data Bivariat Menggunakan SPSS Bagi Dosen STIKES Mandala Waluya Kendari
}

\author{
Fitri Rachmillah Fadmi, La Djabo Buton \\ Progam Studi Kesehatan Masyarakat, STIKES Mandala Waluya Kendari
}

\begin{abstract}
ABSTRAK
Kegiatan pengabdian masyarakat ini dilakukan untuk meningkatkan wawasan, ilmu pengetahuan dan keterampilan para dosen STIKES Mandala Waluya Kendari dalam melakukan analisis data bivariate menggunakan program Statistical Product for Service Solution (SPSS). Peserta dalam kegiatan pengabdian ini sebanyak 15 orang dosen. Metode pelasakanaan kegiatan pengabdian diawali tahap persiapan, pelaksanaan dan evaluasi. Untuk mengukur keberhasilan pelatihan dilakukan pengukuran pre test dan post test. Hasil pelatihan menujukkan bahwa antara nilai pre test dan post test terjadi kenaikan sebesar 15,27 . Hasil uji Paired Sample $t$ test memperoleh nilai $p$-value $<\alpha(0.05)$, Artinya bahwa pelatihan berpengaruh dalam meningkatkan pemahaman peserta. Dengan demikian dapat disimpulkan bahwa kegiatan pelatihan ini cukup berhasil menambah pemahaman peserta dari wawasan, ilmu pengetahuan dan keterampilan bagi peserta pelatihan. Kegiatan pengabdian masyarakat terlaksana secara tertib dan tertib dan teratur Dosen-dosen yang hadir sebagai peserta menanggapi positif pelatihan analisis data bivariat ini.
\end{abstract}

Kata kunci: Pelatihan, Bivariat, SPSS, Dosen

\section{Training Bivariate Data Analysis Using SPSS For Lecturers Mandala College Of Mandala Waluya Kendari Health Science, Kendari}

\begin{abstract}
This community service activity was carried out to improve the insight, knowledge and skills of the STIKES Mandala Waluya Kendari lecturers in conducting bivariate data analysis using the Statistical Product for Service Solution (SPSS) program. Participants in this service activity were 15 lecturers. The method of sensing community service activities begins with the preparation, implementation and evaluation stages. To measure the success of the training, pre-test and post-test measurements were carried out. The results of the training show that between the pre-test and post-test scores an increase of 15.27. Paired Sample $t$ test results obtained p-value $<\alpha(0.05)$, this means that training has an effect on increasing participant understanding. Thus it can be concluded that this training activity was quite successful in increasing participants' understanding of insight, knowledge and skills for the trainees. Community service activities carried out in an orderly and orderly and orderly Lecturers who were present as participants responded positively to this bivariate data analysis training.
\end{abstract}

Keywords : Training, Bivariate, SPSS, Lecture

Penulis Korespondensi :

Fitri Rachmillah Fadmi

Progam Studi Kesehatan Masyarakat, STIKES Mandala Waluya Kendari

E-mail : fitri.rachmillahfadmi@gmail.com

No. Hp : 085241545007 


\section{PENDAHULUAN}

Statistik berperan penting dalam sebuah penelitian, baik dalam penyusunan, perumusan hipotesis, pengumpulan data, penentuan desain penelitian, penentuan jumlah sampel serta yang utama dalam pengolahan dan analisis data. Beberapa hal dalam pengolahan dan analisis data tidak luput dari penggunaan teknik dan metode statistic tertentu yang dapat menjadi tolak ukur dalam menjelaskan hubungan yang terjadi. Salah satu manfaat statistik adalah untuk mengetahui apakah terdapat hubungan kasualitas antara dua atau lebih variable yang benar-benar memiliki keterkaitan dalam suatu kausalitas empiris atau bersifat random atau terjadi secara kebetulan (Arifin, 2014). Statistik juga dapat membantu peneliti dalam menarik kesimpulan untuk mengetahui adanya perbedaan yang diperoleh benar berbeda secara signifikan yang diambil dari sampel representative untuk memberikan inferensi terhadap populasi. Dengan demikian setiap peneliti baik mahasiswa maupun dosen wajib mampu memahami teknik pengolahan dan analisis data (Mundir, 2012).

Menurut Undang-Undang Republik Indonesia Nomor 14 Tahun 2005, dosen merupakan pendidik professional dengan tugas utama mendidik, mengajar, membimbing, mengarahkan, melatih, menilai, dan mengevaluasi peserta didik. Dengan demikin dosen dituntut untuk mengembangkan profesionalitasnya sehingga lebih menjamin dalam meningkatkan kinerjanya (Nasional, 2005). Salah satu cara untuk meningkatkan kinerja keprofesional seorang dosen yakni dengan adanya pendidikan dan latihan (Diklat). Pendidikan dan pelatihan merupakan salah satu bentuk kegiatan dari program pengembangan sumber daya manusia yang strategis yang bertujuan untuk untuk memperoleh kecakapan khusus yang diperlukan oleh dosen dalam menjalankan tri dharma perguruan tinggi yakni mengajar, mengabdi kepada masyarakat dan meneliti (Ningrum, 2014)

Pelatihan statistik merupakan salah satu upaya untuk meningkatkan kompetensi professional dosen. Kemampuan dosen dalam mengolah dan analisis data akan menunjang kinerja dosen dalam menjalankan salah satu tridharma yakni melaksanakan penelitian. Namun demikian, masih terdapat banyak anggapan bahwa pengolahan dan analisis data statistik merupakan hal yang tidak mudah sehingga memilih untuk menyerahkan pengolahan dan analisis data penelitiannya kepada penyedia jasa. hal ini tentu menjadi sangat disayangkan karena kemampuan yang dimiliki dalam mengolah dan menganalisis data akan berpengaruh terhadap interpretasi hasil dan kualitas penelitian. Sebagian besar dosen juga beranggapan bahwa statistik merupakan ilmu yang rumit karena penuh dengan rumus dan perhitungan sehingga membutuhkan ketelitian. Namun seiring dengan semakin berkembang dan majunya teknologi, membuat munculnya berbagai program komputer yang dirancang khusus untuk memudahkan dalam pengolahan dan analisis data statistik. Pengolahan dan analisis data menjadi jauh lebih mudah 
dan terasa meyenangkan tanpa mengurangi kebenaran dan ketepatan outputnya. Salah satu program statistic yang paling popular dikalangan peneliti adalah Statistical Product for Service Solution (SPSS) yang mampu memproses data statistic dengan cepat, tepat dan akurat sehingga masalah perhitungan menjadi ringan dan mudah (Maryati \& Priatna, 2017). Kesulitan yang dihadapi oleh pengguna alat bantu statistik berbasis teknologi informasi seperti SPSS adalah kesulitan dalam menentukan uji yang tepat dan mengoprasikan software SPSS tersebut karena belum terbiasa (Suwarjana, 2016).

Banyak buku yang sudah terbit sebagai pedoman dalam pengolahan dan analisis data statistic, namun masih banyak termasuk dosen yang masih enggan untuk mempelajari sendiri dengan alasan tidak memahami teori, teknik serta dalam menginterpretasikan outputnya. Sementara dosen yang terbiasa menjadi pembimbing tugas akhir mahasiswa pasti sering dihadapkan dengan data yang diolah dengan perangkat lunak statistika seperti SPSS dan sejenisnya (Salwa, Fitriana, \& Aiza, 2016). Data yang sudah diproses dengan perangkat lunak statistik haruslah dianalisa dengan tepat dan juga harus sesuai dengan kebutuhan penelitian. Dengan demikian, perlunya mengadakan pelatihan analisis data bivariat bagi dosen STIKES Mandala Waluya Kendari. Data bivariat dipilih karena analisis data mahasiswa STIKES Mandala Waluya menggunakan jenis data bivariat pada tugas akhirnya. Tujuan kegiatan pengabdian masyarakat ini adalah untuk meningkatkan wawasan, ilmu pengetahuan dan keterampilan para dosen STIKES Mandala Waluya Kendari dalam melakukan analisis data bivariat menggunakan program Statistical Product for Service Solution (SPSS).

\section{METODE}

Metode pelaksanaan pada pengabdian masyarakat ini adalah terdiri dari tiga tahapan yakni tahap pertama adalah tahap persiapan meliputi penetapan jumlah peserta pelatihan, melakukan survey awal dan lokasi pengabdian masyarakat, pemantapan dan penentuan lokasi dan sasaran pengabdian masyarakat, penyusunan materi pelatihan meliputi materi dan modul kegiatan pelatihan serta penyusunan instrument evaluasi kegiatan pelatihan. Selanjutnya tahap kedua adalah tahap pelaksanaan meliputi pengumpulan peserta disuatu tempat dan ruangan yang memadai dan kondusif untuk penyelenggaraan pelatihan yang dilaksanakan dengan tatap muka minimal 8 jam (1 hari) selama 2 (dua) hari, pelaksanaan registrasi dan penerimaan modul serta seminar kid pelatihan. Dalam pemberian materi, pelaksanaan terdiri dari 2 bagian yakni pemaparan materi teori (metode penelitian dan statistik meliputi konsep metode penelitian, konsep inferensial, statistik parametrik dan non parametrik) dan pemaparan praktek (praktek program SPSS dengan menggunakan contoh kasus dan latihan). Tahap ketiga adalah tahap evaluasi meliputi 
pengukuran pengetahuan, wawasan dan keterampilan para dosen terhadap teori statistik serta kemampuan menjalankan program yang dilakukan sebelum dan sesudah kegiatan pelatihan.

\section{HASIL DAN PEMBAHASAN}

Pelatihan analisis data bivariat menggunakan SPSS bagi dosen STIKES Mandala Waluya Kendari dilaksanakan selama 2 (dua) hari dengan jumlah tatap muka selama 8 jam per hari dan bertempat di Aula Lantai II STIKES Mandala Waluya Kendari yang dimbimbing langsung oleh ahli statistik dari STIKES Mandala Waluya.

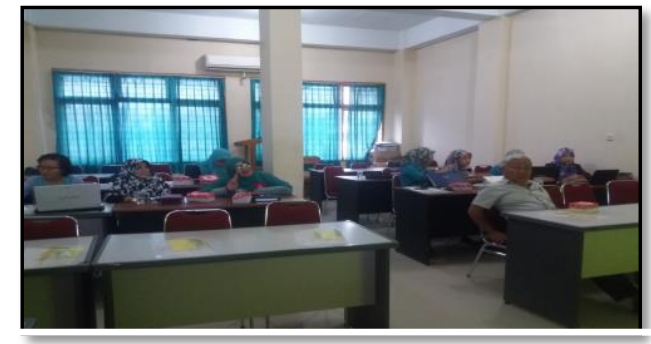

Gambar 1. Peserta pelatihan sedang menyimak materi yang diberikan narasumber
Narasumber merupakan dosen biostatistik dengan kepakaran Biostatistik dan Kependudukan yang diperoleh saat menempuh pendidikan magister di Fakultas Kesehatan Masyarakat (FKM) Universitas Airlangga serta telah mengikuti kegiatan pelatihan-pelatihan statistik. Peserta pelatihan dalam pengabdian masyarakat ini adalah dosendosen STIKES Mandala Waluya Kendari perwakilan program studi kesehatan masyarakat dan keperawatan. Jumlah yang hadir pada saat penyuluhan adalah berjumlah 15 orang. Pelatihan.

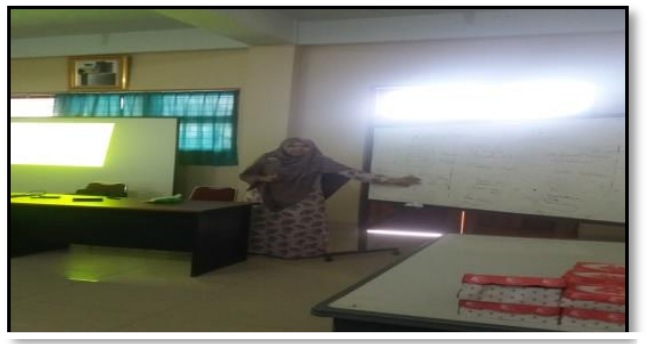

Gambar 2. Narasumber sedang memberikan materi kepada peserta

Independen Sample $\mathrm{t}$ Test, Wilcoxon, Mann-Whitney, Chi-Square dan McNemar, Anova One Way, Regresi Linier dan Regresi Logistik. Pemilihan uji statistik oleh peserta merupakan uji statistic yang paling banyak kurang dipahami oleh peserta.

Peserta dalam kegiatan pengabdian ini memiliki karakteristik yang beragam, mulai dri dosen yunior maupun dosen senior yang sudah lama berkiprah dalam dunia pendidikan sebagai pengajar. Keikutsertaan para peserta dalam kegiatan pengabdian ini karena ingin lebih memahami teori dan 
konsep statistik secara menyeluruh serta cara menjalankan program SPSS dan interpretasi data dengan benar untuk memudahkan mereka dalam membimbing tugas akhir mahasiswa dan dalam melaksanakan penelitia, mengingat setiap dosen wajib memiliki hasil penelitian minimal 2 (dua) dalam setahun yang dipublikasikan dalam bentuk jurnal. Penelitian yang dihasilkan dosen secara umum menggunakan metode kuantitatif dengan pengolahan dan analisis data menggunakan program SPSS.

Adapun karakteristik peserta pelatihan berdasarkan jenis kelamin dan umur tersaji pada tabel 1 berikut.

Tabel 1. Distribusi Peserta berdasarkan jenis kelamin dan umur

\begin{tabular}{|c|c|c|}
\hline Variabel & n & \% \\
\hline Jenis Kelamin & & \\
\hline Laki-Laki & 4 & 26,7 \\
\hline Perempuan & 11 & 73,3 \\
\hline Umur (Tahun) & & \\
\hline $21-30$ & 7 & 46,6 \\
\hline $31-40$ & 6 & 40,0 \\
\hline $41-50$ & 2 & 13,4 \\
\hline
\end{tabular}

Tabel 1 menunjukkan bahwa dari 15 peserta, kategori jenis kelamin terbanyak adalah perempuan berjumlah $11(73,3 \%)$ peserta dan terendah adalah laki-laki berjumlah $4(26,7 \%)$ peserta, kategori umur peserta terbanyak adalah umur 21 - 30 tahun berjumlah 7 (46,6\%) peserta dan terendah berumur $41-50$ tahun berjumlah $2(13,4 \%)$.

Selanjutnya untuk mengukur keberhasilan pelaksanaan kegiatan pelatihan, dilakukan pengukuran pre test dan post test kepada para peserta. Hasil analisis statistik pengukuran pre test dan post test disajikan pada tabel 2 berikut.

Tabel 2. Hasil analisis statistic pre test dan post test

\begin{tabular}{|c|c|c|c|}
\hline Pemahaman Peserta & Mean & $\begin{array}{c}\text { Standard } \\
\text { Deviaion }\end{array}$ & p-value \\
\hline Pre Test & 11,13 & 4,240 & 0 \\
\hline Post Tets & 26,40 & 1,183 & 0,000 \\
\hline
\end{tabular}

Tabel 2 menunjukkan bahwa nilai rata-rata pre test dari total peserta 15 orang adalah 11,13 dengan nilai standar deeviasi sebesar 4,240. Sedangkan nilai rata-rata pada post test adalah 26,92 dengan nilai standar deviasi sebesar 1,183. Antara nilai pre test dan post test terjadi kenaikan sebesar 15,27. Dengan demikian dapat dikatakan kegiatan pelatihan ini cukup berhasil menambah pemahaman peserta dari wawasan, ilmu pengetahuan dan keterampilan bagi peserta pelatihan. Hasil uji normalitas data menggunakan Uji Saphiro Wilk mengasumsikan data berdisitribusi normal, dengan demikian untuk mengetahui pengaruh pelatihan terhadap peningkatan pemahaman peserta 
digunakan uji Paired Sample t test. Hasil uji Paired Sample t test memperoleh nilai $p$-value $<\alpha$ (0.05), maka $\mathrm{H}_{0}$ ditolak. Artinya bahwa pelatihan berpengaruh dalam meningkatkan pemahaman peserta.

Berdasarkan teori perilaku mengungkapkan bahwa tingkat pengetahuan dibagi atas 6 tingkatan domain kognitif yaitu tahu (know) memahami (comprehention), aplikasi (aplication), analisis (analysis), sintesis (synthesis), evaluasi (evaluation) (Notoadmodjo, 2012). Dengan demikian pengetahuan yang dimiliki oleh para peserta pelatihan telah sampai pada tingkatan tahu, namun belum sampai pada tingkat paham serta aplikasi. Artinya bahwa para peserta pelatihan sudah pernah memperoleh materi mengenai metode penelitian dan statistik serta program SPSS namun belum memahami konsepnya secara menyeluruh serta dalam menjalankan program SPSS secara detail. Hasil penelitian ini sejalan dengan penelitian yang dilakukan oleh Fitri, dkk yang mengungkapkan bahwa pelatihan berpengaruh dalam meningkatkan pemahaman peserta tentang teori metode penelitian dan statistik serta praktek analisis data menggunakan SPSS) (Fadmi \& Zulfadlih, 2019). Hasil pelatihan ini juga sejalan dengan kegiatan pengabdian yang dilakukan oleh Jatnika bahwa pelatihan telah berhasil meningkatkan kemampuan peserta (Jatnika, 2018).

\section{KESIMPULAN}

Kegiatan pengabdian masyarakat terlaksana secara tertib dan teratur.
Kegiatan pengabdian masyarakat ini bertujuan untuk meningkatkan wawasan, ilmu pengetahuan dan keterampilan para dosen STIKES Mandala Waluya Kendari dalam melakukan analisis data bivariat menggunakan program Statistical Product for Service Solution (SPSS). Hasil uji statistik menunjukkan bahwa ada pengaruh pelatihan terhadap penigkatan wawasan pengetahuan dan keterampilan dosen STIKES Mandala Waluya Kendari dengan nilai rata-rata sebelum diberikan pelatihan lebih rendah dibandingkan setelah diberikan pelatihan. Dengan demikian kegiatan pelatihan ini dianggap berhasil mencapai tujuan pengabdian masyarakat. Dosen-dosen yang hadir sebagai peserta menanggapi positif pelatihan analisis data bivariat ini karena dirasa pelatihan ini sangat dibutuhkan saat dosen menjadi pembimbing tugas akhir. Peserta bahkan meminta pelatihan serupa di kemudian hari dengan penambahan contoh kasus dan tidak hanya seputar menganalisa data bivariat.

\section{UCAPAN TERIMA KASIH}

Penulis mengucapkan terima kasih kepada seluruh pihak yang telah membantu sehingga pelatihan ini bisa terlaksana hingga selesai. Yayasan Mandala Waluya Kendari selaku pemberi dana, STIKES Mandala Waluya Kendari sebagai penanggung jawab pelaksanaan pengabdian dan LPPM STIKES Mandala Waluya Kendari selaku fasilitator dan 
motivator pengabdi dalam melaksanakan kegiatan pengabdian masyarakat.

\section{DAFTAR PUSTAKA}

Arifin, M. H. (2014). Pengantar Statistika Sosial.

Fadmi, F. R., \& Zulfadlih, L. S. (2019). Pelatihan Program Statistik Spss Bagi Guru Smk Kesehatan Di Kota Kendari. Miracle Journal Of Public Health, 2(2), 162-168.

Jatnika, R. (2018). Pelatihan Unpad Sas (Seri Analisis Statistik) Bagi Dosen Dan Mahasiswa Institut Agama Islam Darussalam Ciamis. Jurnal Pengabdian Kepada Masyarakat, 2(10), 832-835.

Maryati, I., \& Priatna, N. (2017). Analisis Kesulitan dalam Materi Statistika Ditinjau dari Kemampuan Penalaran dan Komunikasi Statistis. Prisma, 6(2), 173-179.

Mundir, M. (2012). Statistik pendidikan; Pengatar analisis data untuk penulisan skripsi dan tesis: STAIN Jember Press.

Nasional, D. P. (2005). Undang-Undang nomor 14 tahun 2005, tentang guru dan dosen. Jakarta: Depdiknas.

Ningrum, I. S. (2014). Strategi Meningkatkan Kompetensi Dosen Universitas Pasir Pengaraian melalui Pendidikan dan Pelatihan. Jurnal Cano Ekonomos, 3(2), 117138.

Notoadmodjo, S. (2012). Pengantar Perilaku Kesehatan dan IImu Perilaku. Jakarta: Penerbit Rineka Cipta.

Salwa, N., Fitriana, A., \& Aiza, J. (2016). Pengaruh Peran Dosen Pembimbing Terhadap Kualitas Tugas Akhir. Journal Biastatistics/ Departemen Statistika FMIPA Universitas Padjadjaran, 10(1), 8-16.

Suwarjana, I. K. (2016). Statistik kesehatan: Penerbit Andi. 